\title{
PRACTICAL USE OF CALCAEROUS FLY ASH IN PORTLAND- COMPOSITE CEMENT CEM II/B-M (V-W) 32,5R INDUSTRIAL PRODUCTION
}

\author{
Zbigniew Giergiczny ${ }^{1}$, Damian Dziuk ${ }^{2}$, Tomasz Pużak ${ }^{3}$, Maciej Batog ${ }^{4}$ \\ ${ }^{1}$ Centrum Technologiczne Betotech Sp. z o.o., ul. Roździeńskiego 14, 41-306 Dąbrowa GórniczaSilesian University of \\ Technology, Faculty of Civil Engineering, ul. Akademicka 5, 44-100 Gliwice, Poland \\ ${ }^{2}$ Centrum Technologiczne Betotech Sp. z o.o., ul. Roździeńskiego 14, 41-306 Dąbrowa Górnicza, Poland \\ ${ }^{3}$ P.V. Prefabet Kluczbork S.A., ul. Kościuszki 33, 46-200 Kluczbork, Poland \\ ${ }^{4}$ Centrum Technologiczne Betotech Sp. z o.o., ul. Roździeńskiego 14, 41-306 Dąbrowa GórniczaSilesian University of \\ Technology, Faculty of Civil Engineering, ul. Akademicka 5, 44-100 Gliwice, Poland
}

\begin{abstract}
Production of Portland clinker, main component of cement, is one of the most determining factor of cement production impact on environment. Use of non-clinker constituents in cement is the principal method of reduction influence of this process on environment. Extension of mineral additives for cement domestic base is important from ecological and economical point of view. Main thesis of this paper was to determine Portland-composite cements with calcareous fly ash addition properties. Results of own research proved that calcareous fly ash has labile chemical composition and physical properties. Positive results of cement mortars were confirmed by concrete tests. Based on laboratory test results, decision on production of Portland-composite cement CEM II/B-M (V-W) 32,5R on an industrial scale was made. Tests results allowed to state that Portland-composite cement CEM $I I / B-M(V-W) 32,5 R$ has similar parameters to other cements available on the market. Concrete tests made with this new cement confirmed similar properties to reference concrete. Results obtained in the thesis give the permission to conclude that in suitable technological conditions (grinding, component selection) calcareous fly ash can be a valuable component of common use cements (CEM II, CEM IV).
\end{abstract}

Keywords: Portland-composite cement, calcareous fly ash, industrial production.

\section{INTRODUCTION}

Portland clinker production is a main element determining arduousness of cement fabrication for the environment. It is connected with natural resources (limestone, marl) and fossil fuels use (hard coal) spend and gases emission (mainly $\mathrm{CO}_{2}$ ) [1]. Application of mineral additives as cement main components is the way to decrease this arduousness. In Polish condition, ground granulated blast furnace slag (S), siliceous fly ash (V) and limestone (LL) lately often been used [2]. There were no tradition and experiences with calcareous fly ash application, which is brown coal burning by-product. Supplies of calcareous fly ash in Poland are estimated about 6 million tons per year. $[3,4]$.

In present paper experiences with calcareous fly ash application in production of Portland-composite cement CEM II/B-M (V-W) 32,5R were presented. Decision about industrial production of this cement type was preceded by wide laboratory and half-industrial research in the realization of project POIG 01.01.02-24-005/09 „Innovative cement binders and concretes with use of calcareous fly ash"

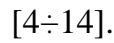

\section{CALCAREOUS FLY ASH CHARACTERISTIC}

Fly ashes used in cement production are divided by reactive $\mathrm{SiO}_{2}$ and $\mathrm{CaO}$ content on: siliceous $-\mathrm{V}$ (content of reactive $\mathrm{SiO}_{2}$ more than $25 \%$ and reactive $\mathrm{CaO}$ below than $10 \%$ ) or calcareous $-\mathrm{W}$ (content of reactive $\mathrm{CaO}$ more than $10 \%$ ) [15]. In comparison to siliceous fly ashes (V), generally used in cement and concrete, calcareous fly ash (W) grains are characterized by irregular shape and porous surface (fig. 1 ), which has negative influence on rheological properties of mortar and fresh concrete $[16 \div 19]$.

The fineness, which is calculated as residue on $0,045 \mathrm{~mm}$ sieve, of unprocessed calcareous fly ash trends upwards in range since $35 \%$ to $65 \%$ [4]. This practically disqualifies the ash as an addition to concrete acc.to standards EN 4501:2012 [21] and ASTM C 618-03 [22]. The common grinding of calcareous fly ash and Portland clinker in the cement mill reduces grains size, crush cenosphers and separates particles compacted as conglomerates (fig. 3). The effect of grinding process is also a higher activity of ground calcareous fly ash (fig. 4). 

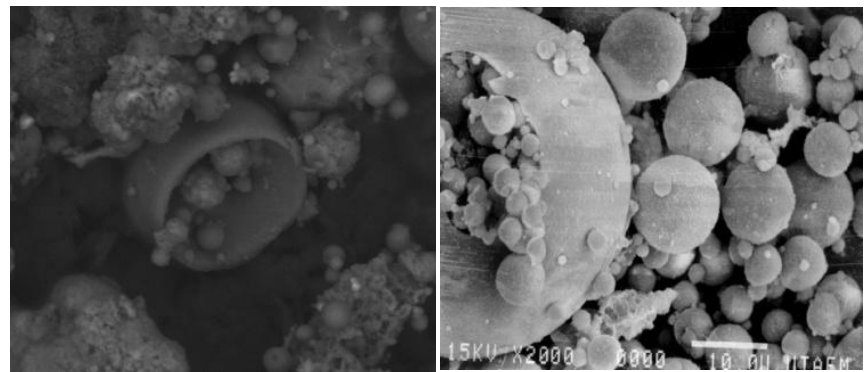

Fig. 1: Fly ash grains morphology: calcareous (W - left side) [19] and siliceous (V - right side) [18]

Chemical composition of fly ash is the result of incombustible remainders of carbon composition. The most often occurring components in fly ashes (calculated as oxides) are: $\mathrm{SiO}_{2} ; \mathrm{Al}_{2} \mathrm{O}_{3} ; \mathrm{Fe}_{2} \mathrm{O}_{3}$ and $\mathrm{CaO}$. Depending on burnt carbon type the amount of $\mathrm{SiO}_{2}+\mathrm{Al}_{2} \mathrm{O}_{3}+\mathrm{Fe}_{2} \mathrm{O}_{3}$ is usually more than $70 \%$ for siliceous fly ash, while in case of calcareous fly ash it contains $10 \div 35 \%$ of $\mathrm{CaO}$ the sum of the three other oxides $\mathrm{SiO} 2+\mathrm{Al} 2 \mathrm{O} 3+\mathrm{Fe} 2 \mathrm{O} 3$ is from $50 \%$ to $70 \%$ [4], [16], [18]. The fig. 2 shows the area of chemical composition, in $\mathrm{CaO}-\mathrm{SiO}_{2}-\mathrm{Al}_{2} \mathrm{O}_{3}$ configuration, calcareous fly ashes in comparison to other cement main components.

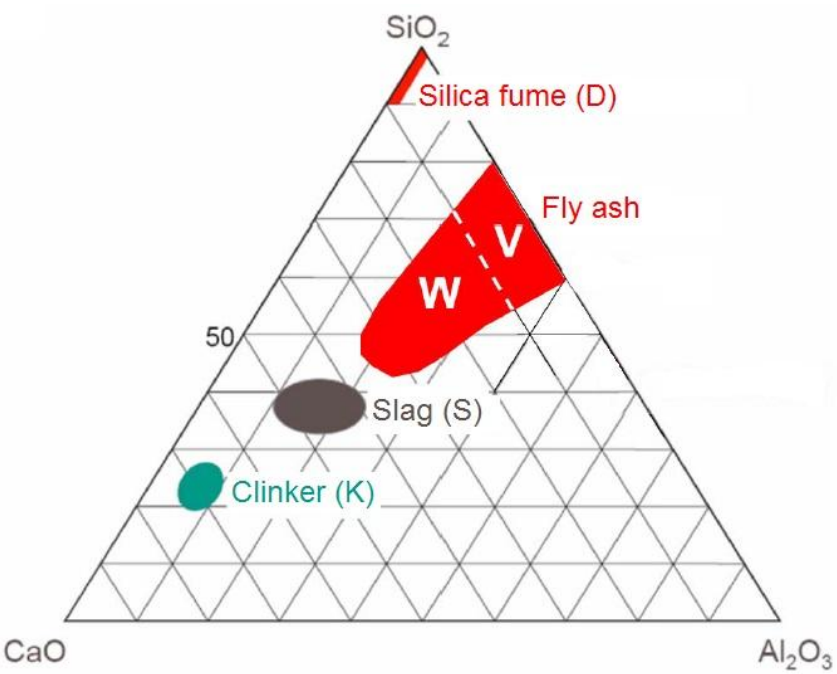

Fig 2: Chemical composition of cement main constituents

[23]

Calcareous fly ashes (W) are characterized by more multiple mineral composition compared with siliceous fly ashes (V). Except typical for siliceous fly ash (V) components, such as: quartz, mullite and hematite, calcareous fly ashes (W) may contain additionally: anhydrite, larnite $\left(\mathrm{C}_{2} \mathrm{~S}\right), \mathrm{C}_{3} \mathrm{~A}$, gehlenite, anortite, free $\mathrm{CaO}$, melilite, merwinite, peryclaise, tenardite and sodalite. Some of these components are reactive to water and they determine the hydraulic activity. Amorphous phase of calcareous fly ashes (alumina-quartzcalcium glass) contains more calcium compounds in compare to amorphous phase of siliceous fly ashes (alumina-quartz glass), which also affects fly ashes

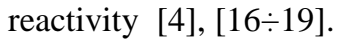
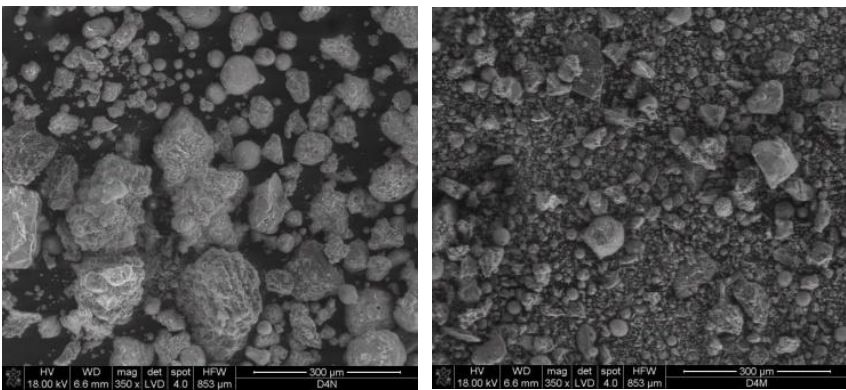

Fig. 3: Morphology of calcareous fly ash grains: unprocessed (left side) and grounded (right side) [19]

Taking into account the chemical and phase composition of calcareous fly ash can be stated that this is a pozzolanhydraulic activity component of cement. This fact was confirmed by many results, which also proved that its

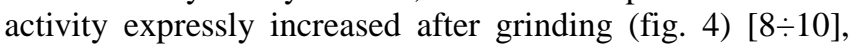

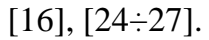

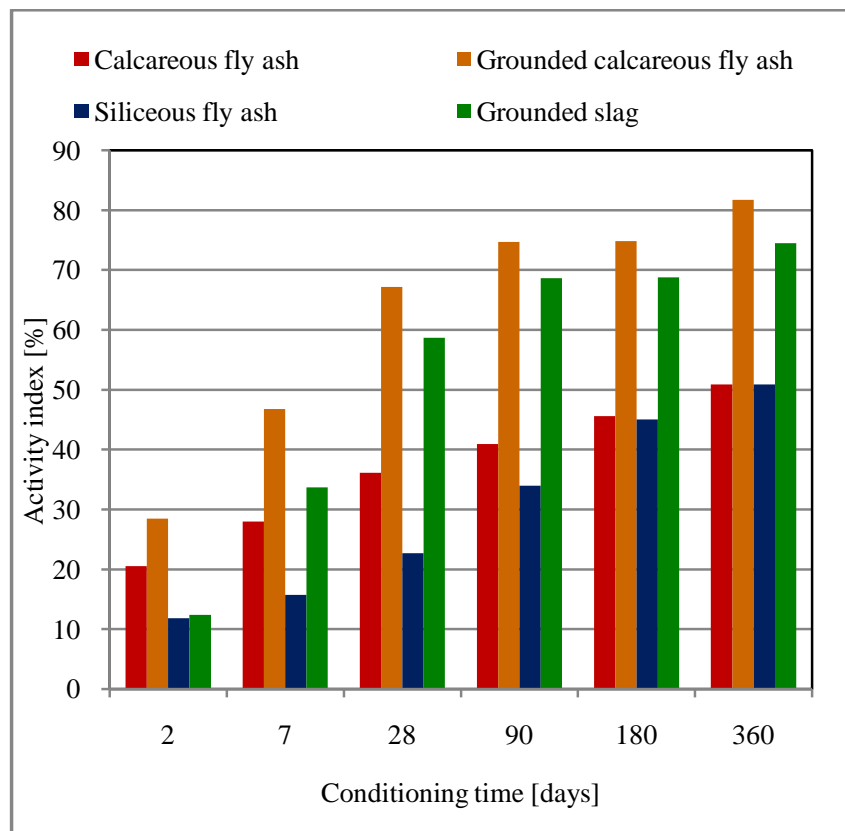

Fig 4: Activity of cement`s components at their $70 \%$ content [19]

\section{INDUSTRIAL PRODUCTION OF}

\section{PORTLAND-COMPOSITE CEMENT CEM II/B-}

\section{32,5R}

In the industrial production of Portland-composite cement CEM II/B-M (V-W) 32,5R was used calcareous fly ash (W), of which standard properties were shown in table 1 .

Table 1 Standard properties of calcareous fly ash (W) [4]

\begin{tabular}{|l|l|l|l|l|}
\hline \multirow{2}{*}{ Property } & \multicolumn{2}{|l|}{ Values } & $\begin{array}{l}\text { Requiremen } \\
\text { ts acc. to }\end{array}$ \\
\cline { 2 - 4 } & $\begin{array}{l}\text { Minimu } \\
\mathrm{m}\end{array}$ & $\begin{array}{l}\text { Averag } \\
\mathrm{e}\end{array}$ & $\begin{array}{l}\text { Maximu } \\
\mathrm{m}\end{array}$ & $\begin{array}{l}\text { EN 197- } \\
1: 2012\end{array}$ \\
\hline $\begin{array}{l}\text { Loss of } \\
\text { ignition } \\
{[\%]}\end{array}$ & 1,7 & 3,7 & 7,2 & $\begin{array}{l}0 \div 5 \\
0 \div 7 \\
0 \div 9\end{array}$ \\
\hline
\end{tabular}




\begin{tabular}{|l|l|l|l|l|}
\hline \multirow{2}{*}{ Property } & \multicolumn{2}{|l|}{ Values } & \multicolumn{2}{|l}{$\begin{array}{l}\text { Requiremen } \\
\text { ts acc. to }\end{array}$} \\
\cline { 2 - 4 } & $\begin{array}{l}\text { Minimu } \\
\mathrm{m}\end{array}$ & $\begin{array}{l}\text { Averag } \\
\mathrm{e}\end{array}$ & $\begin{array}{l}\text { Maximu } \\
\mathrm{m}\end{array}$ & $\begin{array}{l}\text { EN 197- } \\
1: 2012\end{array}$ \\
\hline $\begin{array}{l}\text { Reactive } \\
\mathrm{CaO}[\%]\end{array}$ & 18,0 & 21,0 & 28,0 & $\geq 10,0$ \\
\hline $\begin{array}{l}\text { Reactive } \\
\mathrm{SiO}_{2}[\%]\end{array}$ & 25,0 & 31,0 & 35,0 & $\geq 25,0 *$ \\
\hline $\begin{array}{l}\text { Soundness } \\
{[\mathrm{mm}]}\end{array}$ & 0 & 2 & 5 & $\leq 10$ \\
\hline $\begin{array}{l}\text { Compressi } \\
\text { ve strength } \\
\text { of fly ash } \\
\text { binder }\end{array}$ & 2,5 & 3,5 & 6,5 & $>10,0 * *$ \\
\hline
\end{tabular}

* - relate to fly ash which has reactive $\mathrm{CaO}$ content in range $10 \div 15 \%$

** - relate to fly ash which has reactive $\mathrm{CaO}$ more than 15 $\%$

Results presented in table 1, allow to affirm that applied in cement production calcareous fly ash, fulfills the requirements of standard EN 197-1:2012. Compressive strength of fly ash mortar indeed do not reach requirement of $10 \mathrm{MPa}$, however in author's opinion, with regard to high content of reactive $\mathrm{CaO}$ and $\mathrm{SiO}_{2}$, it should not be disqualifying factor to use this fly ash in cement production. Of key significance is the content of reactive $\mathrm{SiO}_{2}$, which was above $25 \%$. High content of reactive $\mathrm{CaO}$ more than 15 $\%$ can be treat as extra factor which is favorable for the activity.

Portland-composite cement CEM II/B-M (V-W) 32,5R was produced in Górażdże cement plant, 140 thousand tons of this cement was placed on the market.

To reduce the negative impact of fly ash on the rheological properties of calcareous cement decided that:

- calcareous fly ash was be ground together with Portland clinker and setting controller,

- content of calcareous fly ash (W) was limited to approximately $15 \%$

- the second non-clinker cement constituent was siliceous fly ash (V), which was given after milling but before separator (fig. 5).

Combine all components (clinker, fly ashes $\mathrm{W}$ and $\mathrm{V}$, setting controller), cement was pneumatically transported to separator, which separates thick grains (over-grain) from final product, the over-sized grains were transferred back to milling (closed cycle). Adequately milled cement was transported to final product silo.

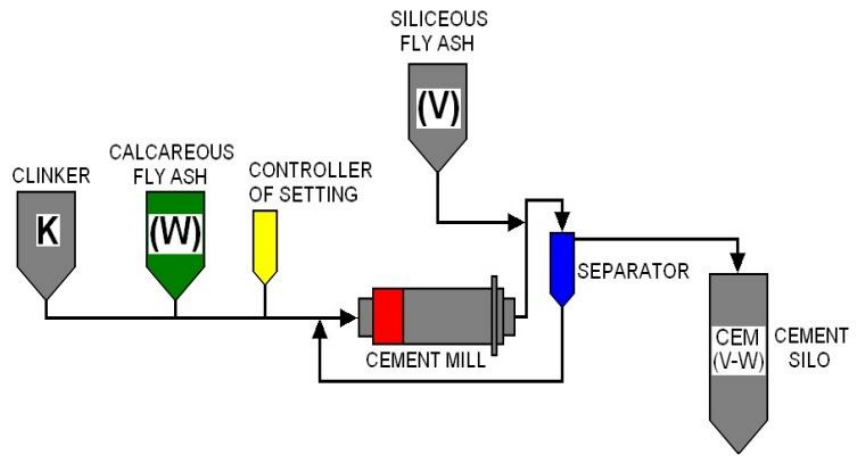

Fig 5: CEM II/B-M (V-W) 32,5R production diagram

In the table 2 the composition of Portland-composite cement CEM II/B-M (V-W) 32,5R was shown and in the table 3 chemical composition of this cement components.

Table 2 Composition of CEM II/B-M (V-W) 32,5R

\begin{tabular}{|l|l|}
\hline Component & Content [\%] \\
\hline Portland clinker & 62,3 \\
\hline Setting controller & 3,8 \\
\hline Siliceous fly ash (V) & 19,5 \\
\hline Calcareous fly ash (W) & 14,4 \\
\hline
\end{tabular}

Table 3 Chemical composition of Portland-composite cement CEM II/B-M (V-W) 32,5R components

\begin{tabular}{|c|c|c|c|c|}
\hline \multirow[b]{2}{*}{$\begin{array}{l}\text { Chemical } \\
\text { component }\end{array}$} & \multicolumn{4}{|c|}{ Cement component } \\
\hline & $\begin{array}{l}\text { Portland } \\
\text { clinker }\end{array}$ & $\begin{array}{l}\text { Setting } \\
\text { controller }\end{array}$ & $\begin{array}{l}\text { Siliceous } \\
\text { fly ash } \\
\text { (V) }\end{array}$ & $\begin{array}{l}\text { Calcareous } \\
\text { fly ash } \\
\text { (W) }\end{array}$ \\
\hline $\begin{array}{l}\text { Loss of } \\
\text { ignition }\end{array}$ & 0,2 & --- & 2,0 & 2,8 \\
\hline $\mathrm{SiO}_{2}$ & 21,7 & 0,9 & 53,2 & 39,3 \\
\hline $\mathrm{Al}_{2} \mathrm{O}_{3}$ & 5,7 & 0,2 & 25,1 & 21,8 \\
\hline $\mathrm{Fe}_{2} \mathrm{O}_{3}$ & 2,9 & 0,2 & 6,6 & 5,5 \\
\hline $\mathrm{CaO}$ & 66,2 & 31,6 & 3,9 & 24,1 \\
\hline Free $\mathrm{CaO}$ & --- & --- & 0,04 & 1,5 \\
\hline $\mathrm{MgO}$ & 1,4 & 0,4 & 2,8 & 1,7 \\
\hline $\mathrm{SO}_{3}$ & 0,5 & 44,2 & 0,4 & 3,2 \\
\hline $\mathrm{Na}_{2} \mathrm{O}$ & 0,2 & 0,1 & 1,1 & 0,2 \\
\hline $\mathrm{K}_{2} \mathrm{O}$ & 0,8 & 0,0 & 3,2 & 0,2 \\
\hline $\mathrm{Cl}^{-}$ & 0,044 & 0,012 & 0,008 & 0,010 \\
\hline
\end{tabular}

Portland-composite cement CEM II/B-M (V-W) 32,5R produced on an industrial scale was characterized by properties shown in table 4 and 5.

Table 4 Properties of CEM II/B-M (V-W) 32,5R according to standard EN 197-1:2012 requirements

\begin{tabular}{|l|l|l|}
\hline Property & Tests results & $\begin{array}{l}\text { EN 197-1:2012 } \\
\text { requirements }\end{array}$ \\
\hline Soundness [mm] & 0,5 & $\leq 10,0$ \\
\hline $\begin{array}{l}\text { Setting time } \\
\text { initial [min] }\end{array}$ & 235 & $\geq 75$ \\
\hline
\end{tabular}




\begin{tabular}{|l|l|l|}
\hline $\begin{array}{l}\text { Compressive } \\
\text { strength after 2 } \\
\text { days [MPa] }\end{array}$ & 19,0 & $\geq 10,0$ \\
\hline $\begin{array}{l}\text { Compressive } \\
\text { strength after 28 } \\
\text { days [MPa] }\end{array}$ & 49,3 & $\geq 32,5$ \\
\hline $\begin{array}{l}\text { Sulphate content } \\
\text { [\%] }\end{array}$ & 2,6 & $\leq 3,5$ \\
\hline $\begin{array}{l}\text { Chloride content } \\
{[\%]}\end{array}$ & 0,07 & $\leq 0,10$ \\
\hline
\end{tabular}

Comparison of results of physical testing of cement CEM II/B-M (V-W) 32,5R with other types of industrially produced cements, showed that this cement, beyond increased water demand, not distinguished by anything in particular. However, it was found that this higher water demand did not affect the consistency of mortars prepared with this cement. (table 5).

Table 5 Properties of different cements

\begin{tabular}{|c|c|c|c|c|c|c|}
\hline $\begin{array}{l}\text { Cement } \\
\text { type }\end{array}$ & $\begin{array}{l}\text { Water } \\
\text { dema } \\
\text { nd } \\
{[\%]}\end{array}$ & $\begin{array}{l}\text { Setti } \\
\text { ng } \\
\text { time } \\
- \\
\text { initia } \\
1 \\
\text { [min] }\end{array}$ & $\begin{array}{l}\text { Soun } \\
\text { d- } \\
\text { ness } \\
{[\mathrm{mm}]}\end{array}$ & $\begin{array}{l}\text { Densi } \\
\text { ty } \\
{[\mathrm{g} / \mathrm{cm}} \\
\left.{ }^{3}\right]\end{array}$ & $\begin{array}{l}\text { Specif } \\
\text { ic } \\
\text { surfac } \\
\mathrm{e} \text { acc. } \\
\text { to } \\
\text { Blain } \\
\mathrm{e} \\
{\left[\mathrm{cm}^{2} /\right.} \\
\mathrm{g}]\end{array}$ & $\begin{array}{l}\text { Flow } \\
\text { of } \\
\text { mort } \\
\text { ar } \\
{[\mathrm{mm}} \\
]\end{array}$ \\
\hline $\begin{array}{l}\mathrm{mi} \\
\mathrm{n} .\end{array}$ & 35,6 & 305 & 1 & 2,86 & 4460 & 193 \\
\hline 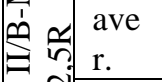 & 31,1 & 235 & 0,6 & 2,90 & 4000 & 184 \\
\hline 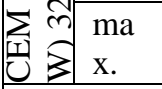 & 29,0 & 195 & 0 & 2,93 & 3600 & 175 \\
\hline $\begin{array}{l}\text { CEM } \\
\mathrm{II} / \mathrm{B}-\mathrm{V} \\
32,5 \mathrm{R} \\
\end{array}$ & 28,0 & 275 & 0,3 & 2,85 & 3340 & 188 \\
\hline $\begin{array}{l}\text { CEM } \\
\text { II/B-S } \\
32,5 \mathrm{R}\end{array}$ & 27,5 & 190 & 0,5 & 3,04 & 3510 & 190 \\
\hline $\begin{array}{l}\text { CEM } \\
\text { III/A } \\
32,5 \mathrm{~N} \\
\end{array}$ & 30,4 & 200 & 0,6 & 3,00 & 3940 & 200 \\
\hline $\begin{array}{l}\text { CEM } \\
\text { III/A } \\
42,5 \mathrm{R} \\
\end{array}$ & 32,6 & 200 & 0,2 & 3,00 & 4380 & 190 \\
\hline $\begin{array}{l}\text { CEM } \\
\text { V/B (S- } \\
\mathrm{V}) \\
32,5 \mathrm{~N} \\
\end{array}$ & 32,0 & 290 & 0,2 & 2,85 & 4270 & 185 \\
\hline
\end{tabular}

Consistency of mortar (flow) with cement CEM II/B-M (VW) 32,5Rwas similar to consistency of mortar with Portland cement CEM I 42,5R (fig. 6). The difference between minimum and maximum value did not exceed $20 \mathrm{~mm}$.

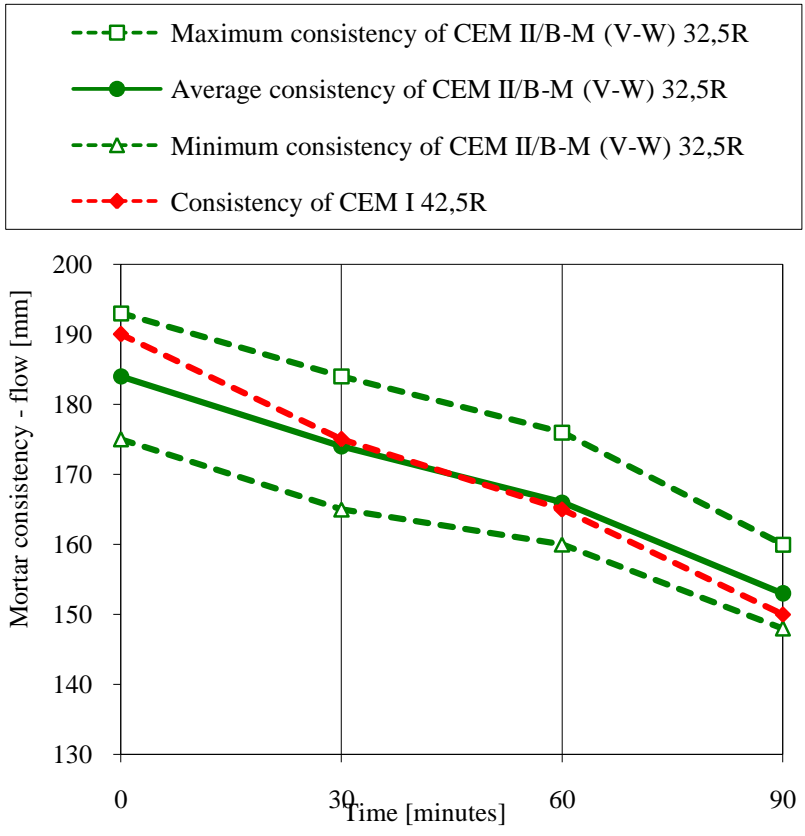

Fig 6: Changes of cement consistency in time.

Compressive strength of Portland-composite cement CEM II/B-M (V-W) 32,5R was, in primary time of hardening, (after 2 and 28 days) similar to Portland-slag cement CEM II/B-S 32,5R. After a longer period of time (28 days and more) its compressive strength was similar to Portland cement CEM I 42,5R (fig. 7).

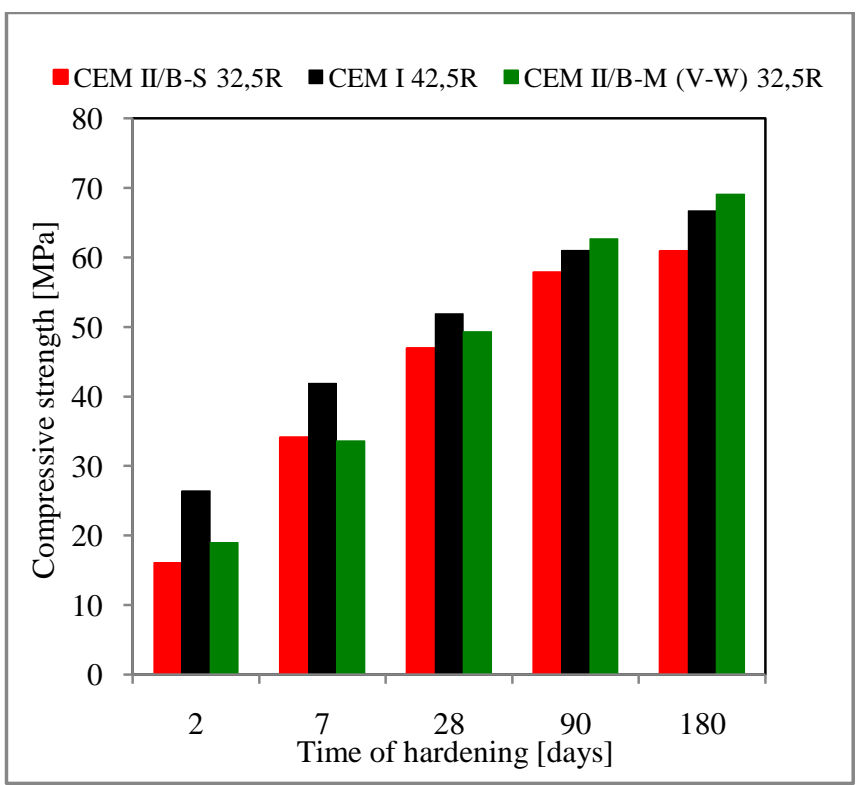

Fig 7: Compressive strength of CEM II/B-M (V-W) 32,5R in comparison to other cements

\section{PROPERTIES OF CONCRETE WITH PORTLAND-COMPOSITE CEMENT CEM II/B-}

\section{32,5R}

On the basis of cement CEM II/B-M (V-W) 32,5R concrete mixture was prepared. Composition of this mixture fulfills 
the requirements acc. to exposition class XF4 after EN 2061:2000 (table 6).

Table 6 Concrete mixture composition

\begin{tabular}{|l|l|}
\hline Component & Content $\left[\mathbf{k g} / \mathbf{m}^{3}\right]$ \\
\hline CEM II/B-M (V-W) 32,5R & 340 \\
\hline Water & 153 \\
\hline Sand 0-2 mm & 665 \\
\hline Gravel 2-8 mm & 510 \\
\hline Gravel $8-16 \mathrm{~mm}$ & 720 \\
\hline
\end{tabular}

water/cement ratio $=0,45$

As a comparison, properties of fresh and hardened concrete with Portland-slag cement CEM II/B-S 32,5R (very popular cement on the domestic market) was accepted.

The air content in both mixtures was the same $-1,8 \%$.

Established consistency class S4 (slump 160 $\div 210 \mathrm{~mm}$ ) for the mixtures was achieved by adding superplastisizer in amount of $1,0 \%$ of cement mass. The consistency was kept at the same level for 90 minutes (fig. 8).

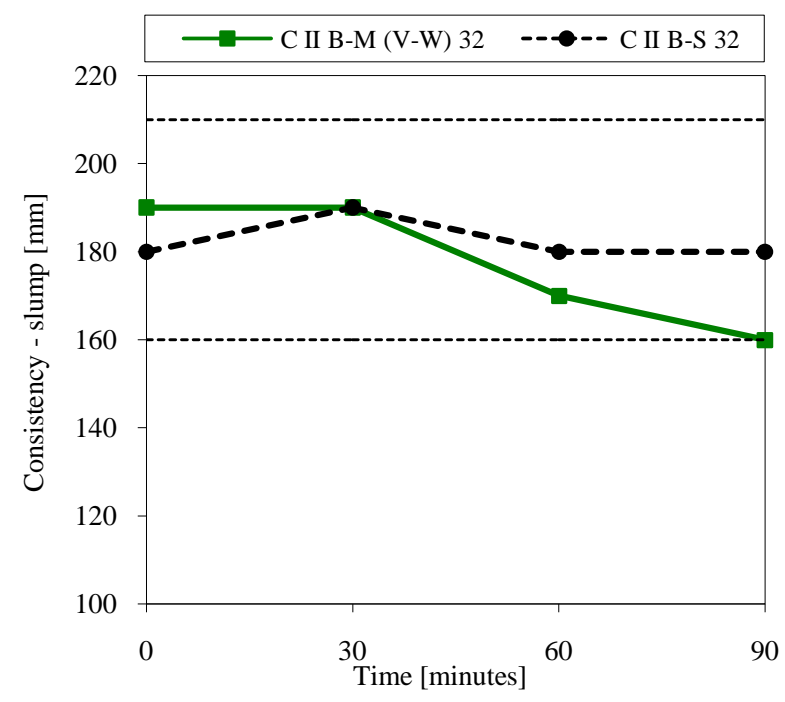

Fig 8: Changes of fresh concretes consistency in time

In relation to mechanical properties, the concrete made with Portland-composite cement CEM II/B-M (V-W) 32,5R has similar parameters to concrete with Portland-slag cement CEM II/B-S 32,5R (tab. 7).

Shrinkage of concrete, tested according to procedure from PN-B-06714-23:1984 [38], made with Portland-composite cement CEM II/B-M (V-W) 32,5R was smaller than concrete with Portland-slag cement CEM II/B-S 32,5R (fig. 9).
Table 7.Mechanical properties of concretes

\begin{tabular}{|c|c|c|}
\hline Properties & $\begin{array}{l}\text { Concrete with } \\
\text { CEM II/B-M } \\
\text { (V-W) 32,5R }\end{array}$ & $\begin{array}{lr}\text { Concrete } & \text { with } \\
\text { CEM II/B-S } \\
\text { 32,5R }\end{array}$ \\
\hline $\begin{array}{ll}\text { Compressive } \\
\text { strength } & \\
\text { after: } & \\
\text { - } & 2 \text { days } \\
- & 7 \text { days } \\
-\quad & 28 \text { days } \\
-\quad & 90 \text { days } \\
\end{array}$ & $\begin{array}{l}27,1 \\
42,0 \\
56,9 \\
73,1\end{array}$ & $\begin{array}{l}26,0 \\
43,7 \\
59,3 \\
71,2\end{array}$ \\
\hline $\begin{array}{l}\text { Flexural strength } \\
\text { [MPa] after: } \\
-\quad 28 \text { days } \\
-\quad 90 \text { days } \\
\end{array}$ & $\begin{array}{l}6,2 \\
7,5\end{array}$ & $\begin{array}{l}7,0 \\
7,5\end{array}$ \\
\hline $\begin{array}{l}\text { Static elasticity } \\
\text { module (E-module) } \\
\text { [GPa] after: } \\
-\quad 28 \text { days } \\
-\quad 90 \text { days } \\
\end{array}$ & $\begin{array}{l}32,7 \\
36,9\end{array}$ & $\begin{array}{l}33,4 \\
37,1\end{array}$ \\
\hline
\end{tabular}

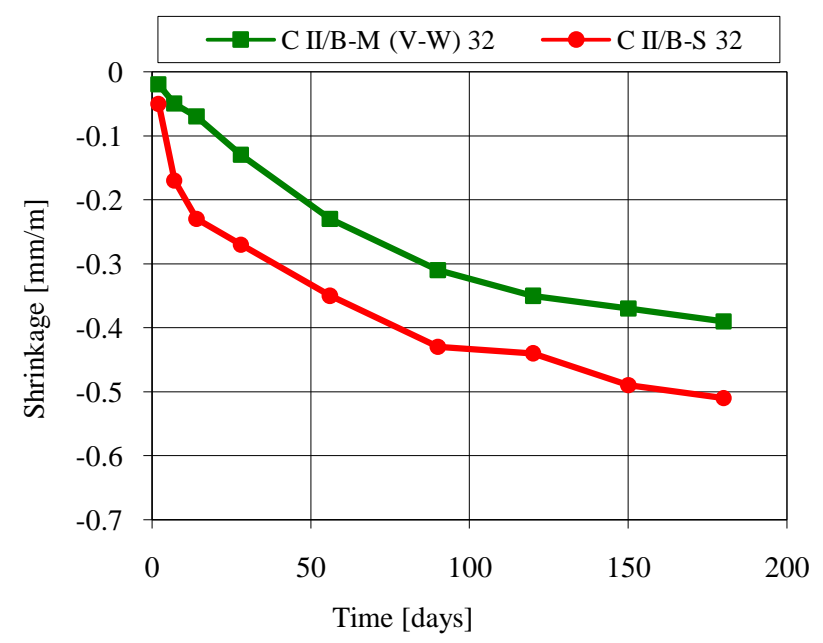

Fig 9: Shrinkage of concretes

Analysis of durability test results (water penetration depth, chloride permeability, carbonation, frost resistance) shows that concrete with Portland-composite cement CEM II/B-M (V-W) 32,5R has similar durableness to concrete with Portland-slag cement CEM II/B-S 32,5R. However both concrete mixtures which were tested on freezing-thawing in the presence of de-icing salt have been aerated to $5.5 \%$ air content in concrete mix. (tab. 8).

Table 8 Durability properties of concretes

\begin{tabular}{|c|c|c|}
\hline Properties & $\begin{array}{l}\text { Concrete with } \\
\text { CEM II/B-M } \\
\text { (V-W) 32,5R }\end{array}$ & $\begin{array}{lr}\text { Concrete } & \text { with } \\
\text { CEM II/B-S } \\
\text { 32,5R }\end{array}$ \\
\hline 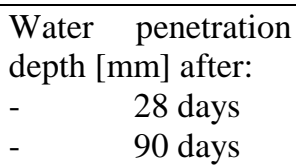 & $\begin{array}{l}20 \\
17\end{array}$ & $\begin{array}{l}19 \\
15\end{array}$ \\
\hline $\begin{array}{ll}\text { Chloride } & \text { ion } \\
\text { permeability } & \text { [C] } \\
\text { after: } & \\
- & \text { 28 days }\end{array}$ & 2320 & 2080 \\
\hline
\end{tabular}




\begin{tabular}{|c|c|c|}
\hline Properties & $\begin{array}{l}\text { Concrete with } \\
\text { CEM II/B-M } \\
\text { (V-W) 32,5R }\end{array}$ & $\begin{array}{l}\text { Concrete with } \\
\text { CEM II/B-S } \\
\text { 32,5R }\end{array}$ \\
\hline 90 days & 670 & 940 \\
\hline $\begin{array}{l}\text { Carbonation depth } \\
{[\mathrm{mm}]}\end{array}$ & 2,5 & 3,0 \\
\hline $\begin{array}{l}\text { Compressive } \\
\text { strength loss (150 } \\
\text { cycles freezing- } \\
\text { thawing) [\%] after: }\end{array}$ & & \\
\hline - $\quad 28$ days & 9,1 & 6,5 \\
\hline$-\quad 90$ days & 1,5 & 2,3 \\
\hline $\begin{array}{l}\text { Slab test (scaling) } \\
{\left[\mathrm{kg} / \mathrm{m}^{2}\right] \text { after: }}\end{array}$ & & \\
\hline - $\quad 28$ days & 0,3 & 0,2 \\
\hline - $\quad 90$ days & 0,2 & 0,0 \\
\hline
\end{tabular}

\section{POSSIBILITIES OF USE PORTLAND-}

\section{COMPOSITE CEMENT CEM II/B-M 32,5R IN}

\section{CIVIL ENGENEERING}

In support of presented researches and other works [4],

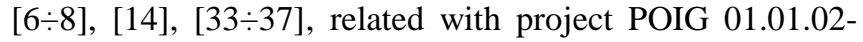
24-005/09 „Innovative cement binders and concretes with use of calcareous fly ash", an author proposed the area of use Portland-composite cement CEM II/B-M (V-W) 32,5R in concrete acc. to exposition class from EN 206-1:2000 (tab. 9).

Table 9 The scope of the use of cement CEM II/B-M (V-W) $32,5 \mathrm{R}$

\begin{tabular}{|c|c|c|}
\hline \multicolumn{2}{|l|}{ Exposition class } & Use \\
\hline \multirow{4}{*}{$\begin{array}{l}\text { Corrosion induced } \\
\text { by carbonation }\end{array}$} & $\mathrm{XC1}$ & + \\
\hline & $\mathrm{XC2}$ & + \\
\hline & $\mathrm{XC3}$ & + \\
\hline & $\mathrm{XC4}$ & + \\
\hline \multirow{3}{*}{$\begin{array}{l}\text { Corrosion induced } \\
\text { by chlorides other } \\
\text { than from sea water }\end{array}$} & XD1 & + \\
\hline & $\mathrm{XD} 2$ & + \\
\hline & XD3 & + \\
\hline \multirow{3}{*}{$\begin{array}{l}\text { Corrosion induced } \\
\text { by chlorides from } \\
\text { the sea water }\end{array}$} & $\mathrm{XS1}$ & + \\
\hline & $\mathrm{XS} 2$ & + \\
\hline & XS3 & + \\
\hline \multirow{4}{*}{$\begin{array}{l}\text { Freeze/thaw attack } \\
\text { with or without de- } \\
\text { icing agents }\end{array}$} & $\mathrm{XF1}$ & + \\
\hline & XF2 & $?$ \\
\hline & $\mathrm{XF3}$ & $?$ \\
\hline & XF4 & $?$ \\
\hline \multirow{3}{*}{ Chemical attack } & XA1 & $? ?$ \\
\hline & $\mathrm{XA2}$ & $? ?$ \\
\hline & XA3 & $? ?$ \\
\hline
\end{tabular}

+ - recommended;

$?$ - proper air content in the mixture;

?? - on condition of sulfate resistance cement tests

The scope mentioned above (tab. 9) is only a proposal and should be verified after practical use of this cement in civil engineering.

\section{CONCLUSIONS}

The results of conducted tests permit to place following conclusions:

- $\quad$ produced in industrial conditions Portlandcomposite cement CEM II/B-M (V-W) 32,5R characterized by properties comparable to other cements Portland-composite cements CEM II/B available on the market;

- $\quad$ the properties of the fresh and hardened concrete with Portland-composite cement CEM II/B-M (VW) $32,5 \mathrm{R}$ were similar to concrete with slag Portland cement CEM II / BS 32.5 R;

- in keeping with appropriate technological conditions (grinding, proper composition) calcareous fly ash (W) can be used as fully valued component of cement and so are: siliceous fly ash (V), limestone (L, LL) or ground granulated blastfurnace slag $(\mathrm{S})$.

\section{ACKNOWLEDGEMENTS}

Research founded partially by project POIG 01.01.02-24005/09 „Innovative cement binders and concretes with use of calcareous fly ash"

\section{REFERENCES}

[1] Neville A.M., Properties of concrete, $5^{\text {th }}$ edition, Polish Cement Asociation 2012 (in polish),

[2] Polish Cement Association Information 2012 www.polskicement.pl (in polish),

[3] Polish Union UPS Information nr 20 / luty 2006 (in polish),

[4] Baran T., Drożdż W., Evaluating of properties of domestic calcareous fly ash and its processing methods, Roads and Bridges - Drogi i Mosty, Volume 12, Number 1/2013, s. 5-16,

[5] Dąbrowska M., Giergiczny Z., Chemical resistance of mortars made of cements with calcareous fly ash, Roads and Bridges - Drogi i Mosty, Volume 12, Number 2/2013, s. 131-146,

[6] Dąbrowski M., Glinicki M.A., Air void system parameters and frost resistance of air-entrained concrete containing calcareous fly ash, Roads and Bridges - Drogi i Mosty, Volume 12, Number 1/2013, s. 41-56,

[7] Drożdż W., Giergiczny Z., The resistance of mortars and concrete with calcareous fly ash on alkaline corrosion, Roads and Bridges - Drogi i Mosty, Volume 12, Number 2/2013, s. 147-158,

[8] Dziuk D., Giergiczny Z., Garbacik A., Calcareous fly ash as a main constituent of common cements, Roads and Bridges - Drogi i Mosty, Volume 12, Number 1/2013, s. 57-70,

[9] Dziuk D., Giergiczny Z., Pużak T., Sokołowski M., The influence of grinding on the efficiency of mineral additives in the composition of cement and concrete, Non-Tradicional Cement \& Concrete IV, ed. by Vlastimir Bilek and Zbynek Kersner, Proceedings of the International Conference, Brno 
University of Technology 2011, s. 465-476,

[10] Giergiczny Z., Garbacik A., Ostrowski M., Pozzolanic and hydraulic activity of calcareous fly ash, Roads and Bridges - Drogi i Mosty, Volume 12, Number $1 / 2013$, s. 71-82,

[11] Giergiczny Z., Synowiec K., Żak A., Suitability evaluation of calcareous fly ash as an active mineral additive to concrete, Roads and Bridges - Drogi i Mosty, Volume 12, Number 1/2013, s. 83-98,

[12] Gołaszewski J., Giergiczny Z., Cygan G., Dziuk D., The effect of high calcium fly ash on the formation of cement properties with its participation, $13^{\text {th }}$ International Congress on the Chemistry of Cement - Madrid 2011,

[13] Gołaszewski J., Ponikiewski T., Kostrzanowska A., The influence of high calcium fly ash on rheological properties of cement mixtures, Non-Tradicional Cement \& Concrete IV, ed. by Vlastimir Bilek and Zbynek Kersner, Proceedings of the International Conference, Brno University of Technology 2011, s. 410-419,

[14] Śliwka A., Domagała K., Zybura A., Evaluation of protective properties of concretes made of cements with calcareous fly ash with respect to reinforcing steel, Roads and Bridges - Drogi i Mosty, Volume 12, Number 2/2013, s. 237-250,

[15] EN 197-1:2012 Cement - Part 1: Composition, specification and conformity criteria for common cements,

[16] Giergiczny Z., The role of calcium and silicous fly ash in the formation of modern binders and cementous materials properties, Cracow University of Technology Publishing House 2006 (in polish),

[17] Giergiczny Z., Fly ash in cement and concrete composition, Silesian University of Technology Publishing House 2013 (in polish),

[18] Huffman M. et all., Use of fly ash in concrete, ACI 232.2R-03,

[19] Dziuk D., The influence of calcareous fly ash on Portland-composite cements properties formation, Dsc. thesis, Promoter Zbigniew Giergiczny, Gliwice 2013 (in polish),

[20] Grzeszczyk S., Lipowski G., Effect of content and particle size distribution of high-calcium fly ash on the rheological properties of cement pastes, Cement and Concrete Research, Vol. 27, No. 6, pp. 907-916, 1997 ,

[21] EN 450-1:2012 Fly ash for concrete - Part 1: Definition, specifications and conformity criteria,

[22] ASTM C 618-03 Standard Specification for Coal Fly Ash and Raw or Calcined Natural Pozzolan for Use in Concrete,

[23] Zając M., Fly Ash properties, Cement Fly Ash Seminar, Stockholm 2008, oral presentation,

[24] Aydin S., Karatay C., Baradan B., The effect of grinding process on mechanical properties and alkali-silica reaction resistance of fly ash incorporated cement mortars, Powder Technology 197 (2010) 68-72,

[25] Chindaprasirt P., Chotithanorm C., Cao H.T.,
Sirivivatnanon V., Influence of fly ash fineness on the chloride penetration of concrete, Construction and Building Materials 21 (2007) 356-361,

[26] Felekoğlu B., Türkel S., Kalyoncu H., Optimization of fineness to maximize the strength activity of highcalcium ground fly ash - Portland cement composites, Construction and Building Materials 23 (2009) 2053-2061,

[27] Tsimas S., Moutsatsou-Tsima A., High-calcium fly ash as the fourth constituent in concrete: problems, solutions and perspectives, Cement \& Concrete Composites 27 (2005) 231-237,

[28] Antiohos S.K., Papageorgiu D., Chaniotakis E., Tsimas S., Mechanical and durability characteristics of gypsum-free blended cements incorporating sulphate-rich reject fly ash, Cement and Concrete Composites 29 (2007) 550-558,

[29] Chindaprasit P., Homwuttiwong S., Sirivivatnanon $\mathrm{V} .$, Influence of fly ash fineness on strength, drying shrinkage an d sulfate resistance of blended cement mortar, Cement and Concrete Research 34 (2004) 1087-1092,

[30] Stefanović G., Ćojbašić L., Sekulić Ž., Matijašević S., Hydration study of mechanically activated mixtures of Portland cement and fly ash, Journal of the Serbian Chemical Society 2007 Volume 72, Issue 6, Pages: 591-604,

[31] Gołaszewski J., Kostrzanowska A., Ponikiewski T., Rheological properties of mixtures with blended cements with siliceous and calacreous flay ash addition, Building Materials 5/2012, str.: 40-43, (in polish)

[32] EN 206-1:2000 Concrete - Part 1: Specification, performance, production and conformity,

[33] Gibas K., Glinicki M.A., Nowowiejski G., Evaluation of impermeability of concrete containing calcareous fly ash in respect to environmental media, Roads and Bridges - Drogi i Mosty, Volume 12, Number 2/2013, str.: 159-172,

[34] Glinicki M.A., Krzywobłocka-Laurów R., Ranachowski Z., Dąbrowski M., Wołowicz J., Microstructure analysis of concrete modified with addition of calcareous fly ash, Roads and Bridges Drogi i Mosty, Volume 12, Number 2/2013, str.: 173-190,

[35] Gołaszewski J., Ponikiewski T., The effect of calacaerous fly ash on selected properties of new generation of concrete, Roads and Bridges - Drogi i Mosty, Volume 12, Number 2/2013, str.: 209-222,

[36] Jóźwiak-Niedźwiedzka D., Sobczak M., Gibas K., Carbonation of concretes containing calacaerous fly ashes, Roads and Bridges - Drogi i Mosty, Volume 12, Number 2/2013, str.: 223-236,

[37] Knor G., Glinicki M.A., Holnicki-Szulc J., Ossowski A., Ranachowski Z., Influence of calcareous fly ash on the temperature of concrete in massive elements during the first 72 hours of hardening, Roads and Bridges - Drogi i Mosty, Volume 12, Number 1/2013, str.: 113-126,

[38] PN-B-06714-23:1984 Mineral aggregates - Testing 
- Volume changes determination by Amsler method,(in polish),

\section{BIOGRAPHIES}

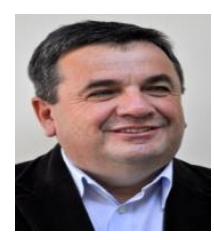

Zbigniew Giergiczny currently is the professor of Civil Engineering Faculty of Silesian University of Technology, Gliwice, Poland. Also works as CEO in Technological Center Betotech and professor. His research interests are in the field of mineral additives in cement and concrete technology.

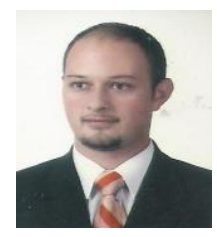

Damian Dziuk, currently working as Deputy Manager of Construction Materials Laboratory in Technological Center Betotech. His research interests are in the field of non-clinker components in the cement.

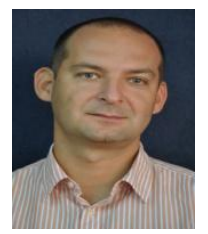

Tomasz Pużak, has received his masters from the Opole University of Technology, Opole, Poland. Currently working as Quality Manager in P.V. Prefabet Kluczbork S.A. His research interests are in the field of precast elements, SCC construction and durability of concrete.

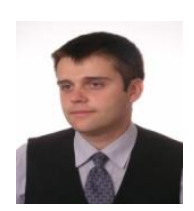

Maciej Batog, has received his masters from the AGH University of Science and Technology, Cracow, Poland. Currently working as R\&D Coordinator in Technological Center Betotech. His research interests are in the field of cements with low clinker content, concrete for massive structures and application of mineral additives in concrete. 